\title{
Effect of Metronidazole on Haematological Parameters in Male Albino Rats
}

\author{
K.O. Oyedeji ${ }^{1}$ And A.F. Bolarinwa ${ }^{2}$ \\ ${ }^{1}$ Department of Physiology, College of Medicine and Health Sciences, Afe Babalola University, Ado-Ekiti, \\ Nigeria. \\ ${ }^{2}$ Department of Physiology, College of Medicine, University of Ibadan, Ibadan, Nigeria.
}

\begin{abstract}
Metronidazole is an antibiotic which is widely used in the treatment of parasitic diseases. Several studies have reported its tumorigenic, mutagenic and antimicrobial effects, but there is a dearth of information on its effect on blood chemistry. This study was designed to investigate its effect on haematological parameters in male albino rats.

Treatment of rats for 25 days with $400 \mathrm{mg} / \mathrm{kg} B W$ of metronidazole caused significant $(p<0.05)$ increase in the packed cell volume (PCV), red blood cell (RBC) and total white blood (TWBC) values relative to their respective controls, but caused no significant $(p>0.05)$ changes in the platelet, neutrophil, lymphocyte, eosinophil and monocyte values relative to their respective controls.

These findings indicate that metronidazole could have some beneficial effects on the blood chemistry of male albino rats.
\end{abstract}

Key words: Metronidazole, Red blood cell, Total white blood cell, Albino rats, Packed cell volume.

\section{Introduction}

Metronidazole is one of those chemotherapeutic agents that been have used in treatment of ailments caused by anaerobic bacteria and certain anaerobic protozoa, such as Trichomonas vaginalis, Entamoeba histolytical, and Giardia lamblia (Dean et. al., 1989). Metronidazole has been reported to induce a reversible bone marrow depression and cytotoxic effects on male mice fertility (El-Nahas and El-Ashmawy, 2004). It has been reported to induce neoplasia (Elizondo et. al., 1994). It is both tumorigenic in rodents and mutagenic in bacteria (Rustia and Shubik, 1972). Long term treatment with metronidazole has been reported to induce significant increase in the frequency of chromosomal abberrations in rats (Mitelman et. al., 1976).

However, due to paucity of information from literature on the effect of metronidazole on haematological parameters in male albino rats, this study aims at investigating the effect of metronidazole on these aforementioned parameters.

\section{Experimental Animals}

\section{Materials And Methods}

Adult male albino rats weighing between $160 \mathrm{~g}$ and $180 \mathrm{~g}$ bred in the Animal House of Physiology Department, LAUTECH, Ogbomoso were used. They were housed under standard laboratory conditions with a 12 hours daylight cycle and had free access to feed and water; they were acclimatized to laboratory conditions for two weeks before the commencement of the experiments. All experiments were carried out in compliance with the recommendations of Helsinki's declaration on guiding principles on care and use of animals.

\section{Drug}

Nigeria.

Metronidazole tablets (Ecomed Pharm Ltd) were bought from Efunbola Pharmacy, Agbowo, Ibadan, Two hundred milligram $(200 \mathrm{mg}$ ) of metronidazole was dissolved in $20 \mathrm{ml}$ of distilled water to give a contration of $10 \mathrm{mg} / \mathrm{ml}$.

\section{Experimental Design}

Ten animals were randomly divided into two groups with each group consisting of five rats. The two groups of rats were subjected to the following oral treatments once a day for 25 days:

Group I rats received $400 \mathrm{mg} / \mathrm{kg}$ BW of Metronidazole

Group II rats received $0.5 \mathrm{ml}$ of distilled water as the control group.

Twenty-four hours (day 26) after the last dosing of the four groups, blood samples were collected.

\section{Collection of Blood Sample}

Blood samples were collected through the medial cantus into EDTA bottles for haematological study. 


\section{Determination of Haematological Parameters}

The red blood cells (RBC) and white blood cells (WBC) counts were determined by the improved Neubauer haemocytometer method. The haemoglobin $(\mathrm{Hb})$ concentration was determined according to Jain (1986), using the cyanomethaemoglobin method. The packed cell volume (PCV) was determined by the microhaematocrit method according to Dacie and Lewis (1991). Schilling method of differential lecukocyte count was used to determine the distribution of the various white blood cells (Mitruka and Rawnsley, 1977). Mean corpuscular volume $(\mathrm{MCV})$, mean corpuscular haemoglobin $(\mathrm{MCH})$ and mean corpuscular haemoglobin concentration (MCHC) were computed according to Jain (1986).

\section{Statistical Analysis}

The mean and standard error of mean (S.E.M.) were calculated for all values. Comparisons between the control and the treated groups were done using the student's t-test. Differences were considered statistically significant at $\mathrm{p}<0.05$.

\section{Effect of metronidazole on haematological parameters}

\section{Results}

The effect of metronidazole at $400 \mathrm{mg} / \mathrm{kg} \mathrm{BW}$ on the haematological parameters of albino rats after treatment of rats for 25 days is shown in the table below.

Treatment of rats with $400 \mathrm{mg} / \mathrm{kg}$ BW of metronidazole caused significant $(\mathrm{p}<0.05)$ increase in the PCV, RBC and TWBC values relative to their respective controls. Treatment of rats with $400 \mathrm{mg} / \mathrm{kg} \mathrm{BW}$ of metronidazole caused no significant ( $p>0.05$ ) change in the $\mathrm{Hb}, \mathrm{MCV}, \mathrm{MCHC}, \mathrm{MCH}$, platelet, neutrophil, lymphocyte, eosinophil and monocyte values relative to their respective controls.

Table 4.33:Effect of Metronidazole on Hematological Parameters after Treatment of Rats for 25 Days (n $\left.=5,{ }^{*} \mathbf{p}<0.05\right)$

\begin{tabular}{|c|c|c|}
\hline Parameters & Control & $400 \mathrm{mg} / \mathrm{kg}$ \\
\hline PCV $(\%)$ & $41.80 \pm 1.03$ & $46.50 \pm 0.65 *$ \\
\hline $\mathrm{Hb}(\mathrm{g} / \mathrm{dl})$ & $13.90 \pm 0.41$ & $13.00 \pm 1.66$ \\
\hline $\operatorname{RBC}\left(\times 10^{6} / \mu \mathrm{l}\right)$ & $7.07 \pm 0.27$ & $7.74 \pm 0.07 *$ \\
\hline $\mathrm{MCV}(\mathrm{FL})$ & $59.10 \pm 0.78$ & $59.90 \pm 0.29$ \\
\hline MCHC (g/dl) & $33.40 \pm 0.25$ & $33.70 \pm 0.70$ \\
\hline $\mathrm{MCH}(\mathrm{pg})$ & $19.90 \pm 0.32$ & $20.10 \pm 0.51$ \\
\hline $\operatorname{TWBC}\left(\times 10^{3} / \mu \mathrm{L}\right)$ & $11.00 \pm 0.42$ & $14.00 \pm 0.05^{*}$ \\
\hline Platelets $\left(10^{5} / \mu \mathrm{L}\right)$ & $1.10 \pm 0.10$ & $1.10 \pm 0.03$ \\
\hline Neutrophils (\%) & $27.00 \pm 0.41$ & $25.30 \pm 1.65$ \\
\hline Lymphocytes (\%) & $68.00 \pm 0.41$ & $68.80 \pm 1.25$ \\
\hline Eosinophils (\%) & $2.25 \pm 0.48$ & $1.50 \pm 0.29$ \\
\hline Monocytes (\%) & $2.75 \pm 0.63$ & $3.50 \pm 0.29$ \\
\hline
\end{tabular}

\section{Discussion}

This study has revealed that metronidazole caused significant increase in the PCV and RBC values. This suggests that metronidazole has the potential to stimulate erythropoietin releases from the kidneys with a resultant increase in the rat of RBC production (erythropoiesis) which could ultimately induce polycythemia, since it has been reported that values of RBC and associated parameters lower than normal ranges are indicative of anaemic conditions while higher values are suggestive of polycythemia (American Diabetes Association, 2000). It could also indicate that there was an enhancement in the oxygen-carrying capacity of blood and the amount of oxygen delivered to the tissues since RBC and haemoglobin are very important in transferring respiratory gases (De Gruchy, 1976). Contrary report was given by Adedapo et al (2007) in P.amarus treated rats.

The significant increase in TWBC count induced by metronidazole suggests an enhancement in the immune system. Similar report was given by Adewusi and Afolayan (2009) in Pelargonium reniforme extract treated rats.

The insignificant change in neutrophil count caused by metronidazole probably indicates that the ability of the body to attack and destroy invading bacteria, viruses and other injurious agents (Phagocytosis) has not been compromised. The non-significant change in lymphocyte count suggests that the acquired immune responses of the body has not been compromised by metronidazole; the non- significant change in monocyte count probably indicates that the phagocytic function of the body has not been compromised by metronidazole. The non - significant change in eosinophil count probably indicates that the anti-allergic and anti-parasitic infectious response of the body have not been compromised by Metronidazole. Also, the insignificant change in 
the platelet count caused by metronidazole could be an indication that it does not has the potential to stimulate thrombopoietin production (Li et al., 1999) with hemostatic capability of the blood maintaining the status quo since platelets mediate in the blood-clotting mechanism.

Metronidazole caused non - significant changes in the MCV and MCH values which could be an indication of absence of macrocytic anaemia, since increased $\mathrm{MCV}$ an $\mathrm{MCH}$ values are known to be indicative of macrocytic anaemia. Also, metronidazole caused non- significant change in the MCHC value which suggest and absence of hereditary spherocytosis since MCHC values are known to be elevated in hereditary spherocytosis.

In conclusion, this study has shown that metronidazole could have some beneficial potentials on the blood chemistry of albino rats. However, its effect on human blood chemistry is unknown, nevertheless, considering these findings in animal model, metronidazole is thus recommended as a food supplement.

\section{References}

[1] Adedapo A.A, Abatan MO, Olorunsogo O.O (2007): Effects of some plants of the spurge family on haematological and biochemical parameters in rats. VETERINARSKI ARHIV 77 (1), $29-38$.

[2] Adewusi EA, Afolayan AJ (2009): Safety evaluation of the extract from the roots of Pelargonium reniforme Curtis in male wistar rats. Afr. J. Pharm and Pharmacology, vol. 3(8): pp. $368-373$

[3] American Diabetes Association (2000): Nutrition recommendation and principles for people with diabetes mellitus clinical practice recommendations Diabetes care 23:543-6.

[4] Dacie JV, Lewis SM (1991): Practical haematology, 7th edition ELBS with Churchill Livingston, England, pp 37-85.

[5] Das UK, De D, Chatterjee K, Mallick C, Bera TK, Ghosh D (2009): Antigonadal effect induced by hydro-methanolic extract of leaf of Aelgle mermelos in male rat: Effect of hCG co-administration. Journal of Medicinal Plants Research Vol. 3(10), Pp728 - 735.

[6] De Gruchy GC (1976): Clinical haematology in Medical Practice. Blackwell Scientific Publication. Oxford, London pp. 33-57.

[7] Dean H.J, Cornacoff BJ, Rosenthal JG, Luster I. (198): Immune System: Evaluation of Injury. In; Hayes AW, Editor. Principles and Methods of Toxicology. New York: Raven Press; 1989.

[8] Elizondo G, Montero R, Herrera JE, Hong E, Ostrosky-Wegman P. (1994): Lymphocyte proliferation kinetics and sister-chromatid exchanges in individuals treated with metronidazole. Mutat Res (2): 133-7.

[9] El-Nahas AF, El-Ashmawy (2004): Reproductive and cytogenetic toxicity of metronidazole in male mice. Pharmacol Toxicol 2004; $5: 226-31$

[10] Jain NC (1986): Schalm's Veterinary Haematology 4th ed. Lea and Fabiger, Philadelphia.

[11] Li Y, Xia, Kuter DJ (1999): Interaction of thrombopoietin with the platelet complements receptor in plasma: binding, internalization, stability and pharmacokinetics. Brit J. Haematol 106: 345.

[12] McClain RM, Downing JC, John EE (1988): Effect of metronidazole on fertility and testicular function in male rats. Journal of Toxicological science, volume 12, number 3, pp 396.

[13] Mitelman F, Levan G, Nilsson PG, Brandt L. (1976): Non-radom karyotypic evolution in chronic myeloid leukemia. Int J Cancer 18: 24-30.

[14] Mitruka BM, Rawnsley H (1977): Clinical, biochemical and haematological references values in normal experimental animals. Masson Publishing USA Inc. Pp. 53-54.

[15] Rustia M, Shubik P. (1972): Induction of lung tumors and malignant lymphomas in mice by metronidazole. J. Natl Cancer Inst. 48 (3): 721-729. 